\title{
TARIK MENARIK KEWENANGAN PEMERINTAH PUSAT DAN PEMERINTAH ACEH DALAM PENGESAHAN QANUN BENDERA DAN LAMBANG ACEH
}

Fadhil Ilhamsyah

Fakultas Ilmu Sosial dan Ilmu Politik, Universitas Teuku Umar email: ilhamsyah355@gmail.com

\begin{abstract}
This research examines the relationship of the authority of the Central Government and the Acehnese Government in endorsement Qanun flag and emblem of Aceh. This study uses qualitative methods, in which the source data is obtained with the technique of librarianship and in-depth interviews. From the results of this research show that the relation is the authority of the Central Government and the Acehnese Government in endorsement Qanun flag and emblem of Aceh going on and entwined on the authority, namely the supervision and attestation against Qanun. The Government of Aceh was given the authority to set a then the Qanun is evaluated by the Central Government to ensure that the Qanun has set are not contrary to the public interest, Qanun, and regulations legislation is higher.
\end{abstract}

Keywords: Authority, Aceh flag and emblem 


\section{PENDAHULUAN}

Sejak awal proklamasi kemerdekaan Indonesia pada 17 Agustus 1945, hubungan Aceh dan Pemerintah Pusat mengalami pasang surut. Dalam cacatan sejarah Indonesia, pada awal kemerdekaan hubungan Aceh dan Pemerintah Pusat sangat harmonis. Ini tergambarkan pada sumbangsih rakyat Aceh dalam perjuangan mempertahankan Republik Indonesia dari jajahan Belanda. Akan tetapi, pasca Indonesia bebas dari jajahan pada tahun 1950 an, hubungan Aceh dan Pemerintah Pusat diwarnai dengan pemberontakan yang dilakukan oleh rakyat Aceh terhadap Pemerintah Pusat.

Pemberontakan Aceh terhadap Pemerintah Pusat pertama kali dilakukan oleh Tgk Daud Beureueh pada tahun 1953, yang menyatakan Aceh menjadi bagian gerakan Negara Islam Indonesia (NII) pimpinan SM Kartosuwiryo di Jawa Barat. Pemberontakan ini muncul karena kekecewaan rakyat Aceh atas tidak ditepatinya janji Presiden Soekarno yang akan memberikan otonomi khusus dengan penerapan syariat islam di Aceh. Pemberontakan Tgk Daud Beureueh kemudian berlanjut dengan pemberontakan yang dipelopori oleh Hasan Muhammad di Tiro. Pada 4 Desember 1976, Hasan Muhammad di Tiro memproklamirkan Gerakan Aceh Merdeka (GAM) yang bertujuan membentuk Negara Aceh dan memisahkan diri dari Negara Kesatuan Republik Indonesia (NKRI). Pemberontakan GAM dilandasi pada kekecewaan rakyat Aceh atas ketidakadilan dalam pembagian hasil sumber daya alam di Aceh oleh Pemerintah Pusat.

Konflik vertikal antara Aceh dan Pemerintah Pusat berlangsung dalam kurun waktu puluhan tahun sejak GAM diproklamirkan oleh Hasan Muhammad di Tiro pada 4 Desember 1976. Seiring berjalannya waktu, konflik tersebut dapat diakhiri dengan kesepakatan damai antara Pemerintah Indonesia dengan GAM. Kesepakatan damai keduanya tertera dalam Memorandum of Understanding (MoU) antara Pemerintah Indonesia dan GAM yang ditandatangani pada 15 Agustus 2005 di Helsinki, Finlandia. Melalui kesepakatan tersebut, Pemerintah Indonesia memberikan otonomi khusus kepada Aceh sebagai resolusi terhadap konflik panjang antara Pemerintah Indonesia dan GAM yang menuntut keadilan dan ingin memisahkan Aceh dari NKRI. Hasil kesepakatan tersebut kemudian dituangkan dalam UndangUndang Nomor 11 Tahun 2006 Tentang Pemerintahan Aceh (UUPA).

Pasca reformasi tahun 1998, konsep otonomi khusus atau desentralisasi asimetris mulai banyak diperbincangkan di Indonesia. Otonomi khusus diyakini dapat meredamkan tuntutan daerah yang ingin memisahkan diri dari NKRI. Atas dasar tersebut, Majelis Permusyawaratan Rakyat (MPR) mengeluarkan Ketetapan MPR No. IV/MPR/1999 dan Ketetapan MPR No. IV/MPR/2000 tentang rekomendasi kebijakan dalam penyelenggaraan otonomi daerah dan mengubah Pasal 18 UUD 1945 menjadi Pasal 18, Pasal 18A, dan Pasal 18B yang kemudian menjadi landasan bagi pelaksanaan otonomi khusus di Indonesia (Saldi Isra, 2013: 55).

Sebagai tindak lanjut dari perubahan-perubahan di atas, disahkan lah UU No. 18 Tahun 2001 tentang Otonomi Khusus bagi Daerah Istimewa Aceh sebagai Provinsi Nanggroe Aceh Darussalam (UU ini dibatalkan setelah disahkannya UU Nomor 11 Tahun 2006 tentang Pemerintahan Aceh) dan UU No. 21 Tahun 2001 tentang Otonomi Khusus bagi Provinsi Papua. Pengesahan undang-undang di atas selain sebagai perintah dari UUD 1945, juga sebagai pengaturan terhadap pembagian kewenagan dan pola relasi antara Pemerintah Pusat dan Pemerintah Daerah yang diberikan status otonomi khusus.

UUPA sebagai landasan hukum yang mengatur pelaksanaan otonomi khusus di Aceh memiliki beberapa perangkat pelaksana Undang-Undang atau turunan Undang-Undang, yaitu 10 Peraturan Pemerintah (PP), 3 Peraturan Presiden (Perpres), 59 Qanun Aceh serta 10 Qanun Kabupaten/Kota. Perangkat pelaksana Undang-Undang berupa PP dan Perpres menjadi kewenangan Pemerintah Pusat untuk menerbitkannya dan Perangkat pelaksana Undang-Undang berupa Qanun (Perda) Aceh dan Qanun Kabupaten/Kota menjadi kewenangan Pemerintah Aceh dan Pemerintah Kabupaten/Kota dalam menerbitkannya. Dalam menerbitkan perangkat pelaksana Undang-Undang tersebut harus disetujui antara Pemerintah Pusat dan Pemerintah 
Aceh. Salah satu yang menjadi perangkat pelaksana UUPA adalah Qanun tentang Bendera dan Lambang Aceh. Qanun ini merupakan implementasi dari angka 1.1.5. MoU Helsinki, yang kemudian dijelaskan pada pasal 246 ayat (2) dan pasal 247 ayat (1) Undang-Undang Pemerintahan Aceh (UUPA) yaitu Pemerintah Aceh diberikannya hak untuk menentukan dan menetapkan bendera dan lambang Provinsi Aceh sebagai simbol keistimewaan dan kekhususan tersebut. Dasar hukum terhadap pengakuan simbol dan kekhususan Aceh tersebut perlu diatur dalam suatu Qanun Aceh.

Pada tahun 2013 Pemerintah Aceh dan Dewan Perwakilan Rakyat Aceh (DPRA) telah mengesahkan Qanun Bendera dan Lambang Aceh. Akan tetapi, pengesahan Qanun Bendera dan Lambang Aceh tersebut sampai saat ini masih terjadi tarik menarik antara Pemerintah Pusat dan Pemerintah Aceh. Pemerintah Pusat berpandangan bahwa Qanun yang telah disahkan masih bermasalah karena bertentangan dengan Peraturan Pemerintah No 77 Tahun 2007 sehingga Qanun tersebut belum dapat dijalankan. Disisi yang lain, Pemerintah Aceh dan Dewan Perwakilan Rakyat Aceh (DPRA) berpandangan bahwa Qanun Bendera dan Lambang Aceh sudah dapat dijalankan dan Pemerintah Pusat tidak bisa membatalkannya. Artikel ini akan membahas lebih lanjut tentang kewenangan antara Pemerintah Pusat dan Pemerintah Aceh menurut Undang-Undang Pemerintah Aceh (UUPA) dan bagaimana relasi Pemerintah Pusat dan Pemerintah Aceh dalam pengesahan Qanun Bendera dan Lambang Aceh.

\section{Desentralisasi Asimetris}

Desentralisasi asimetris adalah sub kajian dari konsep desentralisasi. Untuk menjelaskan desentralisasi asimetris, maka terlebih dahulu dijelaskan apa yang di maksud dengan desentralisasi. Menurut World Bank dalam Krismiyati Tasrin (2012 : 7), desentralisasi didefinisikan sebagai transfer kewenangan dan tanggungjawab penanganan fungsi publik dari pemerintah pusat kepada pemerintah di bawahnya atau kepada organisasi semi pemerintah (quasy government) atau kepada sektor swasta. Sementara itu, Smith dengan mengadopsi definisi desentralisasi menurut Rondinelli sebagaimana dijelaskan dalam Krismiyati Tasrin (2012 : 7), menjelaskan bahwa desentralisasi merupakan transfer tanggungjawab perencanaan (planning), manajemen, penerimaan dan pengalokasian sumber daya (resource raising and allocation) dari pemerintah pusat kepada: (a) lembaga/instansi perwakilan pusat di daerah; (b) unit atau tingkatan pemerintahan yang lebih rendah; (c) lembaga semi otonom; (d) institusi fungsional di daerah; atau (e) organisasi swasta.

Pendapat serupa diungkapkan Escobar-Lemmon dalam Leo Agustino (2014: 14) yang menjelaskan desentralisasi sebagai pemindahan otoritas, fungsi dan tanggung jawab untuk memformulasikan kebijakan dan keputusan dari pemerintah pusat kepada pemerintah daerah. Penjelasan ini menegaskan bahwa pemerintah daerah memiliki kuasa atau wewenang untuk membuat program dan peraturan sesuai keadaan wilayahnya.

Lebih lanjut Bayu Dardias Kurniadi (2012 : 3) menjelaskan bahwa desentralisasi merupakan pola relasi antara pemerintah pusat dan daerah yang didalamnya mengatur hubungan terkait dengan aspek kewenangan, kelembagaan, keuangan dan kontrol. Bentuk relasi pusat dan daerah tersebut memiliki perbedaan antara kerangka negara kesatuan dan negara federal. Dalam negara kesatuan, seluruh bagian negara dikelola oleh pemerintah pusat. Karena luas wilayah dan karakter daerah yang luas, disamping keterbatasan pemerintah pusat untuk menangani seluruh urusan pemerintahan yang menjamin pelayanan publik, maka beberapa urusan diserahkan ke pemerintahan daerah. Hal ini berbeda dengan bentuk federal dimana bagian dari negara federal pada dasarnya adalah negara-negara bagian yang menyatu menjadi satu negara. Urusan yang tidak bisa dilakukan negara bagian, misalnya yang menyangkut hubungan lintas negara bagian, diserahkan ke pemerintah federal. Jika pada negara kesatuan kewenangan yang diberikan ke daerah merupakan pemberian pemerintah pusat, dalam negara federal urusan pemerintah federal disepakati diantara negara-negara bagian. 
Berdasarkan penjelasan berbagai ilmuan diatas, dapat disimpulkan bahwa desentralisasi adalah penyerahan kewenangan, otoritas dan tanggung jawab dari Pemerintah Pusat kepada Pemerintah Daerah atau tingkatan pemerintahan yang rendah untuk dapat membuat kebijakan atau peraturan bagi daerah tersebut, yang kemudian dalam menjalankan kewenangan tersebut akan membentuk pola relasi antara pemerintah pusat dan daerah yang mengatur hubungan terkait dengan aspek kewenangan, kelembagaan, keuangan dan kontrol.

Secara teoritik, Muhammad Labolo (2014 : 7) menjelaskan bahwa model desentralisasi terdiri dalam desentralisasi simetris dan desentralisasi asimetris. Lebih lanjut Charles Tarlton dalam Robert Jaweng (2011 : 162) menjelaskan perbedaan paling dasar antara desentralisasi biasa atau simetris dan desentralisasi asimetris terletak pada tingkat kesesuaian (conformity), dan keumuman (commonality) pada hubungan suatu level pemerintahan (negara bagian atau daerah) dengan sistem politik, dengan pemerintah pusat maupun antar negara bagian atau daerah. Pola simetris ditandai oleh 'the level of conformity and commonality in the relations of each separate political unit of the system to both the sytem as a whole and to the component units'. Disini, hubungan simetris antar setiap unit lokal dengan pemerintah pusat tersebut didasari jumlah dan bobot kewenangan yang sama".

Sementara, dalam posisi asimetris, satu atau lebih unit politik atau pemerintahan lokal "possessed of varying degrees of autonomy and power". Berbedanya derajat kekuasaan berupa ketidak seragaman pengaturan muatan kewenangan itu membentuk derajat hubungan yang berbeda pula antar Negara bagian/daerah asimetris dengan unit-unit politik lainnya, baik secara horizontal (antar daerah) maupun vertikal (dengan pusat). Khusus mengenai pola asimetris, Tarlton menekankan, "in the model asymmetrical system each component unit would have about it a unique feature or set of features would separet in important ways, its interest from those of any other state or the system considered as a whole".

Kerangka pikir Tarlton di atas kemudian diadopsi oleh John Mc Garry dari Queen's University, Canada. Titik tekannya tidak hanya terkait substansi asimetri tetapi juga bentuk dasar legal pengaturan nya. Menurut McGarry dalam Robert Jaweng (2011: 163) model asimetri terjadi kalau otonomi semua unit pemerintahan subnasional dijamin konsitusi dan terdapat sekurangnya satu unit lokal yang menikmati level otonomi yang berbeda (umumnya otonomi yang lebih luas). Di Negara federal, sekaligus sebagai kebalikan dari Negara unitaris, keberadaan asimetris diatur dalam konstitusi dan otoritas federal tidak bisa secara sepihak menarik atau membatalkan status otonomi tersebut. Dalam perspekstif politik, asimetri yang diatur dalam konstitusi ini adalah bukti pengakuan Negara akan keberagaman sifat nasional satu atau lebih wilayah.

Dalam pelaksanaan dan pemberian desentralisasi asimetris bagi suatu daerah, ada beberapa pertimbangan yang akan mempengaruhi keputusan pemerintah pusat. Menurut Cornelis Lay dalam Robert Jaweng (2011 : 165) menyebutkan ada sejumlah alasan atau dasar pertimbangan dalam pemberian desentralisasi asimetris, yaitu : "Pertama, tantangan yang bersifat politik, terutama terkait tuntunan separatisme di daerah; Kedua, keunikan budaya dan perbedaan alur kesejarahan, termasuk perlindungan bagi kaum minoritas; Ketiga, tantangan teknokratikmanajerial, yakni keterlibatan kapasitas suatu daerah dalam menjalankan fungsi dasar pemerintahan; Keempat, masalah competitivenes suatu bangsa dengan basis daya saing suatu daerah khusus ekonomi; Kelima, adanya resiko bagi wilayah tertentu, terutama yang terletak di wilayah perbatasan.

Dalam prakteknya, konsep desentralisasi asimetris telah banyak diadopsi dibeberapa negara, seperti di Quebec di Kanada, Mindanao di Filipina, Bougainville di Papua New Guinea, Basque di Spanyol, dan Aceh, Papua, Papua Barat, Yogyakarta, dan Jakarta di Indonesia. Pemberian status desentralisasi asimetris dibeberapa negara tersebut didasari kepada strategi komprehensif pemerintah pusat guna merangkul kembali daerah yang hendak memisahkan diri dari pemerintah pusat atau negara. Pemberian status desentralisasi asimetris diiringi oleh 
pemberian kewenangan yang berbeda dengan daerah-daerah lainnya di negaranya seperti diperbolehkan memiliki bendera, bahasa, partai politik lokal, polisi lokal, dan bagi hasil sumber-sumber pendapatan yang lebih besar (Djoehermansyah Djohan, 2013: 122).

Pelaksanaan desentralisasi asimetris dengan pemberian otonomi khusus juga memiliki beberapa resiko terutama bagi negara kesatuan. Otonomi khusus yang diterapkan di negara kesatuan memiliki kecenderungan kearah negara federalis atau bahkan self-government dan merangsang pemisahan diri. Menurut McGarry dalam Robert Jaweng (2011: 166) secara politik, model asimetris dinilai bisa mendorong tendensi pemisahan diri. Model asimetris memungkinkan pemerintahan lokal memiliki tanggung jawab khusus bagi warganya, sementara pada sisi lain hal itu berarti justru kian mengurangi tanggung jawab dan ruang keterlibatan pemerintah nasional atas wilayah asimetris dan warga di dalamnya. Kepercayaan diri yang tinggi di kalangan unit lokal dan minimnya ruang bagi kehadiran pemerintahan nasional bisa menjadi insentif gerakan sentrifugal.

Berdasarkan penjelasan diatas, dapat disimpulkan bahwa desentralisasi aiameteris ialah penyerahan kewenangan atau otoritas dari Pemerintah Pusat kepada suatu daerah dengan derajat atau tingkatan kewenangan yang khusus dan berbeda dengan daerah-daerah lainnya. Pemberian desentralisasi asimetris oleh Pemerintah Pusat kepada suatu daerah didasari atas beberapa pertimbangan yaitu sebagai resolusi atas tuntutan separatisme di daerah, pengakuan terhadap keunikan budaya, sebagai pusat teknokratik-manajerial pemerintahan negara atau sebagai Ibukota negara, sebagai pengembangan ekonomi tertentu, dan sebagai perlindungan terhadap wilayah-wilayah tertentu seperti wilayah perbatasan negara.

\section{METODE PENELITIAN}

Kajian ini menggunakan metode kualitatif, yaitu suatu proses penelitian dan pemahaman yang berdasarkan pada metodologi yang menyelidiki suatu fenomena sosial dan masalah manusia. Pada pendekatan ini, peneliti menjelaskan suatu gambaran kompleks, meneliti katakata, laporan terinci dari pandangan responden, dan melakukan studi pada situasi yang alami. Data penelitian ini bersumber dari data primer dan data sekunder. Data primer diperoleh melalui wawancara dengan informan yang dipilih dengan teknik purposive sampling atau pengambilan sampel secara bertujuan. Peneliti akan memilih informan yang dianggap mengalami, mengetahui dan dapat dipercaya untuk menjadi sumber data yang memiliki kebenaran dan pengetahuan yang mendalam terhadap masalah penelitian ini. Sedangkan data sekunder diperoleh dari studi kepustakaan antara lain buku-buku, jurnal, disertasi/tesis/skripsi penelitian, surat kabar dan media elektronik.

\section{HASIL DAN PEMBAHASAN}

\section{Kewenangan Pemerintah Pusat dan Pemerintah Aceh Menurut Undang-Undang Nomor 11 Tahun 2006 Tentang Pemerintah Aceh}

Menurut Cornelis Lay dalam Robert Jaweng (2011 : 165), salah satu alasan atau dasar pertimbangan diberikannya desentralisasi asimetris bagi suatu daerah ialah adanya tuntutan kemerdekaan oleh kelompok seperatisme di daerah. Otonomi Khusus Aceh yang dijabarkan dalam Undang-Undang Nomor 11 Tahun 2006 tentang Pemerintahan Aceh merupakan tindak lanjut dari perjanjian damai atau Memorandum Of Understanding (MoU) antara Pemerintah Republik Indonesia dan Gerakan Aceh Merdeka (GAM) terhadap konflik yang menuntut kemerdekaan Aceh oleh GAM yang telah terjadi puluhan tahun di Aceh. Melalui undangundang ini, Pemerintah Indonesia mempertegas kewenangan dan derajat otonomi khusus yang diberikan kepada Aceh dengan mengadopsi butiran-butiran MoU Helsinki dan undang-undang yang mengatur otonomi khusus Aceh sebelumnya yaitu UU Nomor 18 Tahun 2001.

Undang Nomor 11 Tahun 2006 Tentang Pemerintah Aceh (UUPA) terdiri atas 40 Bab dan 273 Pasal. Undang-undang inilah yang saat ini mengatur tentang otonomi yang seluas-luasnya 
bagi Aceh terutama kewenangan khusus di bidang politik, ekonomi, dan sosial budaya untuk sebesar-besarnya kesejahteraan rakyat Aceh. Kewenangan khusus tersebut pada intinya adalah sebagai berikut (Djoehermansyah Djohan, 2013: 130-133):

1) Kewenangan Aceh/Kabupaten/Kota.

a. Pemerintah Aceh dan Kabupaten/Kota berwenang mengatur dan mengurus urusan pemerintahan dalam semua sektor publik, kecuali urusan pemerintahan yang menjadi kewenangan pemerintah, yang meliputi: urusan pemerintahan yang bersifat nasional, politik luar negeri, pertahanan, keamanan, yustisi, moneter, dan fiskal nasional, dan urusan tertentu dalam bidang agama.

b. Pengaturan tentang rencana persetujuan internasional yang berkaitan langsung dengan Aceh yang dibuat oleh Pemerintah dilakukan dengan konsultasi dan pertimbangan DPRA.

c. Pengaturan tentang kebijakan administratif yang berkaitan langsung dengan Aceh yang akan dibuat oleh Pemerintah dilakukan dengan konsultasi dan pertimbangan Gubernur dan rencana pembentukan UU oleh DPR yang berkaitan langsung dengan Aceh dilakukan dengan konsultasi dan per-timbangan DPRA.

d. Pemerintah Aceh dapat mengadakan kerja sama dengan lembaga atau badan di luar negeri kecuali yang menjadi kewenangan Pemerintah; dan dapat berpartisipasi secara langsung dalam kegiatan seni, budaya, dan olahraga internasional.

2) Pembagian Urusan Pemerintahan.

a. Urusan pemerintahan yang menjadi kewenangannya akan diatur dan diurus sendiri oleh Aceh dan peme- rintah kabupaten/kota dan pelaksanaan pem-bagian urusan pemerintahan dilakukan berdasarkan kriteria eksternalitas, akuntabilitas, dan efisiensi, dengan memperhatikan keserasian hubungan antar pemerintahan di Aceh.

b. Pengaturan tentang urusan wajib yang menjadi ke-wenangan Pemerintah Aceh dan Kabupaten/Kota, serta urusan wajib lainnya yang menjadi kewenangan pemerintah Aceh sebagai pelaksanaan keistimewaan Aceh serta urusan pemerintahan yang bersifat pilihan diatur dalam Qanun Aceh dengan berpedoman pada peraturan perundangundangan.

3) Penyelenggaraan PILKADA

a. PILKADA di Aceh dilaksanakan oleh Komisi Independen Pemilihan (KIP).

b. Peserta PILKADA di Aceh dapat diajukan oleh partai politik atau gabungan partai politik, partai lokal atau gabungan partai lokal, gabungan partai politik dan partai lokal, dan calon perseorangan.

4) Partai Politik Lokal

a. Penduduk Aceh dapat membentuk Parpol lokal yang didirikan dan dibentuk, oleh sekurang-kurangnya 50 orang WNI yang telah berusia 21 tahun dengan sekurangkurangnya 30\% perempuan dan sudah berdomisili tetap di Aceh.

b. Partai politik lokal dapat ikut serta dalam Pemilu Legislatif anggota DPRA dan DPRK Kab/Kota dan PILKADA Gubernur dan Wakil Gubernur atau Bupati dan Wakil Bupati atau Walikota dan Wakil Walikota.

5) Bendera, Lambang dan Hymne

Pengaturan tentang Bendera, Lambang dan Hymne Aceh dalam UU ini diatur sebagai berikut:

a. Bendera Merah Putih merupakan lambang Bendera Nasional yang berlaku bagi Aceh dalam NKRI dan UUD 1945.

b. Pemerintah Aceh dapat menentukan dan menetapkan Bendera dan Lambang yang mencerminkan simbol keistimewaan dan kekhususan Aceh, dan bukan merupakan simbol kedaulatan dan tidak diberlakukan sebagai bendera kedaulatan di Aceh.

c. Lagu Indonesia Raya merupakan lagu kebangsaan yang bersifat nasional bagi Aceh 
dalam NKRI dan

d. Pemerintah Aceh dapat menetapkan Hymne Aceh seba-gai pencerminan keistimewaan dan kekhususan Aceh.

6) Bidang Perekonomian

Dalam bidang perekonomian, antara lain dibuat pengaturan tentang hak dan kewenangan

Pemerintah Aceh dalam pengelolaan sumber daya alam (SDA) di Aceh sebagai berikut:

a. Pengelolaan SDA;

Pemerintah Aceh/Kabupaten/Kota mengelola SDA di Aceh, baik di darat maupun di laut sesuai dengan kewenangannya, yang meliputi perencanaan, pelaksanaan, pemanfaatan dan pengawasan kegiatan usaha yang dapat berupa eksplorasi, eksploitasi dan budi daya, dengan menerapkan prinsip transparansi dan pembangunan berkelanjutan, yang pelaksanaan-nya dengan memberdayakan masyarakat secara maksimal dengan mengikutsertakan SDM setempat dan sumber daya lainnya yang ada di Aceh.

b. Sektor perikanan dan kelautan;

Pemerintah Aceh/Kabupaten/Kota berwenang mengelola SDA yang hidup di laut teritorial Aceh, serta berwenang menerbitkan izin penangkapan ikan dan pengusahaan SDA laut lainnya di laut sekitar Aceh sesuai kewenangannya.

c. Sektor perdagangan dan investasi;

- Penduduk di Aceh dapat melakukan perdagangan dan investasi secara internal dan internasional sesuai dengan peraturan perundang-undangan.

- Pemerintah Aceh/Kabupaten/Kota, sesuai kewenangannya dapat menarik wisatawan asing dan memberikan izin yang terkait dengan investasi dengan memperhatikan norma, standar, prosedur dan kriteria yang berlaku secara nasional, dan meng-acu pada prinsip-prinsip pelayanan publik yang cepat, tepat, murah, dan prosedur yang sederhana, yang akan diatur dalam Qanun Aceh dengan berpedoman pada peraturan perundang-undangan.

7) Sumber Penerimaan Aceh

Sumber penerimaan Aceh, selain terdiri atas pendapatan asli daerah, pinjaman daerah, lainlain penerimaan daerah yang sah, juga memperoleh dana perimbangan dari bagi hasil dari hidrokarbon sebagai dana khusus, serta akan mendapat dana tambahan, dengan pengaturan sebagai berikut:

a. Dana Khusus penyelenggaraan pemerintahan di Aceh dari dana perimbangan bagi hasil Penerimaan Negara Bukan Pajak yang bersumber dari hidrokarbon sebesar 70\%, yaitu dari sektor pertambangan minyak memperoleh tambahan penerimaan sebesar 55\% (secara nasional 15\%) dan sektor pertambangan gas bumi memperoleh tambahan penerimaan sebesar $40 \%$ (secara nasional $30 \%$ ).

b. Dana Otonomi Khusus yang ditujukan untuk pembia-yaan pembangunan dan pemeliharaan infrastruktur, pemberdayaan ekonomi rakyat, pengentasan kemiskinan, serta pendanaan pendidikan, sosial dan kesehatan sebesar $2 \%$ plafon DAU Nasional selama 15 (lima belas) tahun dan kemudian 1\% plafon DAU Nasional selama 5 (lima) tahun.

8) Perubahan nama Aceh dan gelar Pejabat Pemerintahan yang dipilih.

a. Nama Aceh sebagai daerah provinsi dan gelar pejabat pemerintahan yang dipilih akan ditentukan setelah Pemilu tahun 2009.

b. Nama dan gelar tersebut, akan ditetapkan dengan Pe-raturan Pemerintah (PP) berdasarkan usul dari DPRA dan Gubernur Aceh.

9) Wali Nanggroe dan Lembaga Adat

a. Aceh dapat membentuk lembaga Wali Nanggroe sebagai lembaga kepemimpinan adat sebagai pemersatu masyarakat yang independen, berwibawa, dan berwenang membina 
dan mengawasi penyelenggaraan kehidupan lembaga-lembaga adat, adat istiadat, dan pemberian gelar/derajat dan upacara-upacara adat lainnya. Lembaga Wali Nanggroe di pimpin oleh seorang Wali Nanggroe yang bersifat independen dan bukan merupakan lembaga politik.

b. Aceh dapat membentuk lembaga-lembaga adat seperti Majelis Adat Aceh, Imeum Mukim, Tuha Peut, Tuha Lapan, Imeum Meunasah atau lembaga adat lainnya sebagai wahana partisipasi masyarakat dalam penyelenggaraan Pemerintahan Aceh, Kabupaten/Kota di bidang keamanan, ketentraman, kerukunan, dan ketertiban masyarakat.

10) Syariat Islam

Pemerintah Aceh dapat menerapkan Syariat Islam di Provinsi Aceh yang meliputi ibadah, ahwal al-syakhshiyah (hukum keluarga), muamalah (hukum perdata), jinayah (hukum pidana), qadha' (peradilan), tarbiyah (pendidikan), dakwah, syiar, dan pembelaan Islam.

11) Pengangkatan Kapolda dan Kajati Aceh

Dalam hal pengangkatan Kapolda dan Kajati di Aceh, Kepala Kepolisian Republik Indonesia dan Jaksa Agung harus mendapat persetujuan tertulis dari Gubernur Aceh.

12) Pengaturan Lain-Lain:

a. Substansi tentang: Pembagian Aceh; Azas; Bentuk dan Susunan Penyelenggara Pemerintahan; DPRA/DPRK, Pemerintah Aceh/ Kabupaten/Kota; Tugas, Wewenang, Kewajiban, Larangan dan Pemberhentian Gubernur/ Bupati/Walikota; Kepegawaian; Pembentukan Qanun; dan Pembinaan dan Pengawasan pemerintahan, disesuaikan dan mengikuti pengaturan dalam UU Nomor 32 Tahun 2004 dan peraturan perundangundangan lainnya.

b. Kantor Wilayah Badan Pertanahan Nasional (BPN) Aceh dan BPN Kabupaten/Kota menjadi perangkat daerah Aceh dan perangkat daerah Kabupaten/Kota.

Berdasarkan uraian di atas, kewenangan-kewenangan yang diberikan pemerintah kepada Aceh dalam UU Pemerintahan Aceh ini sungguh sangat luas. Sebagaimana yang dijelaskan Charles Tarlton bahwa yang membedakan desentralisasi simetris dengan desentralisasi asimetris ialah jumlah atau derajat kewenangan yang diberikan. Daerah-daerah yang memberlakukan desentralisasi asimetris memilki jumlah atau derajat yang beragam atau berbeda dengan daerahdaerah yang memberlakukan desentralisasi simetris. Dari berbagai kewenangan yang diberikan Pemerintah Pusat kepada Pemerintah Aceh telah menunjukkan bahwa adanya ketidakseragaman atau perbedaan derajat otonomi yang diperoleh Aceh dibandingkan dengan daerah-daerah lainnya di Indonesia khususnya di bidang politik, ekonomi, dan sosial budaya.

Di bidang politik, Aceh diperbolehkan untuk membentuk partai politik lokal, sementara di daerah-daerah lain tidak diperkenankan serta memiliki kewenangan untuk dimintakan konsultasi dan pertimbangan oleh Pemerintah Pusat terhadap rancangan undang-undang, pengaturan kebijakan administratif dan perjanjian internasional yang berkaitan langsung dengan Aceh. Kemudian di bidang ekonomi, Aceh memperoleh dana Otonomi Khusus sebesar 2\% plafon DAU Nasional selama 15 (lima belas) tahun dan kemudian sebesar 1\% plafon DAU Nasional selama 5 (lima) tahun berikutnya serta berhak menerima dana hasil perimbangan bagi hasil Penerimaan Negara Bukan Pajak yang bersumber dari hidrokrabon sebesar $70 \%$. Di bidang sosial budaya, Aceh dapat membentuk lembaga adat, lembaga Wali Nanggroe, Majelis Permusyawaratan Ulama, Mahkamah Syariyah, merubah nama Aceh dan gelar pejabat pemerintahannya serta dapat memiliki bendera, lambang dan himne sebagai simbol keistimewaan dan kekhususan.

Jika dibandingkan dengan praktek desentralisasi asimetris di beberapa negara seperti di Quebec di Kanada, Mindanao di Filipina, Bougainville di Papua New Guinea, Basque di Spanyol, otonomi khusus Aceh memiliki persamaan dari alasan atau dasar pertimbangan 
pemberian otonomi yaitu sebagai resolusi konflik atas tuntutan kemerdekaan. Selain itu, kesamaan lainnya juga dapat dilihat dari kewenangan-kewenangan yang diberikan seperti diperbolehkan memiliki bendera, lambang, himne, partai politik lokal, dan juga bagi hasil sumber-sumber pendapatan yang lebih besar dibandingkan daerah-daerah lainnya.

Dengan kewenangan yang begitu besar dan luas yang diberikan kepada Aceh tidak membuat Pemerintah Pusat kehilangan kewenangannya. Pemerintah Pusat tetap memiliki kewenangan dalam urusan pemerintahan absolut yang tidak diserahkan kepada daerah yaitu urusan pemerintahan yang bersifat nasional, politik luar negeri, pertahanan, keamanan, yustisi, moneter, dan fiskal nasional, dan urusan tertentu dalam bidang agama. Selain itu, Pemerintah Pusat tetap memiliki kewenangan dalam melakukan pengawasan terhadap Qanun Aceh dan Qanun Kabupaten/Kota serta pembinaan dan pengawasan penyelenggaraan Pemerintahan Aceh dan Pemerintahan Kabupaten/Kota di Aceh. Pembinaan dan Pengawasan dapat dilakukan sendiri oleh Pemerintah terhadap Pemerintah Aceh atau dilimpahkan kepada Gubernur sebagai wakil pemerintah untuk pembinaan dan pengawasan terhadap kabupaten/kota.

\section{Relasi Kewenangan Pemerintah Pusat dan Pemerintah Aceh Dalam Pengesahan Qanun Bendera Dan Lambang Aceh}

Pada dasarnya desentralisasi merupakan pola relasi antara Pemerintah Pusat dan Pemerintah Daerah yang didalamnya mengatur hubungan terkait dengan aspek kewenangan, kelembagaan, keuangan dan kontrol. Pola relasi antara Pemerintah Pusat dan Pemerintah Daerah tersebut dijabarkan dan diatur dalam sebuah regulasi berupa undang-undang. Melalui undang-undang akan dijelaskan tentang pembagian kewenangan antara Pemerintah Pusat dan Pemerintah Daerah dalam melaksanakan urusan pemerintahan yang meliputi aspek politik, kelembagaan, keuangan serta aspek pembinaan dan pengawasannya. Dengan kata lain, relasi antara Pemerintah Pusat dan Pemerintah Daerah akan terjalin ketika masing-masing melakukan kewenangannya.

Undang-undang Nomor 11 Tahun 2006 tentang Pemerintahan Aceh (UUPA) merupakan regulasi yang mengatur desentralisasi atau otonomi di Aceh. Sebagai landasan hukum yang mengatur pelaksanaan otonomi khusus di Aceh, UUPA memiliki beberapa perangkat pelaksana Undang-Undang atau turunan Undang-Undang, yaitu 10 Peraturan Pemerintah (PP), 3 Peraturan Presiden (Perpres), 59 Qanun Aceh serta 10 Qanun Kabupaten/Kota. Perangkat pelaksana Undang-Undang berupa PP dan Perpres menjadi kewenangan Pemerintah Pusat untuk menerbitkannya dan Perangkat pelaksana Undang-Undang berupa Qanun (Perda) Aceh dan Qanun Kabupaten/Kota menjadi kewenangan Pemerintah Aceh dan Pemerintah Kabupaten/Kota dalam menerbitkannya. Dalam menerbitkan perangkat pelaksana Undang-Undang tersebut harus disetujui antara Pemerintah Pusat dan Pemerintah Aceh.

Di antara beberapa perangkat pelaksana UUPA, tulisan ini hanya akan membahas salah satu turunan UUPA yaitu turunan UUPA yang mengatur tentang bendera dan lambang Aceh. Sesuai dengan Pasal 246 dan Pasal 247 UUPA, pengaturan terhadap bendera dan lambang Aceh di atur dalam Qanun Aceh. Qanun Aceh adalah peraturan perundang-undangan sejenis peraturan daerah provinsi yang mengatur penyelenggaraan pemerintahan dan kehidupan masyarakat Aceh. Qanun Aceh disahkan oleh Gubernur Aceh setelah dibahas dan mendapatkan persetujuan bersama dengan DPRA. Setelah disahkan Qanun Aceh diundangkan dalam lembaran daerah.

Di samping itu, sebagaimana yang dijelaskan dalam Pasal 235 UUPA, Pemerintah Pusat melakukan pengawasan terhadap Qanun Aceh sesuai dengan peraturan perundang-undangan. Pengawasan yang dilakukan oleh Pemerintah Pusat untuk memastikan bahwa Qanun yang telah disahkan oleh Gubernur bersama DPRA tidak bertentangan dengan ketentuan umum, antar Qanun dan peraturan perundang-undangan yang lebih tinggi. Pengawasan yang dilakukan oleh Pemerintah Pusat berupa evaluasi, revisi, penangguhan, sampai dengan pembatalan Qanun. Artinya mekanisme pengawasan terhadap Qanun yang dilakukan oleh Pemerintah Pusat sama 
dengan mekanisme pengawasan terhadap Peraturan Daerah (Perda) di daerah-daerah lain di Indonesia yaitu pengawasan preventif dan represif yang berpedoman kepada Undang-Undang No. 32 Tahun 2004 (Jum Anggraini, 2011: 326-332)..

Sebagaimana dijelaskan di atas, bahwa pengaturan tentang bendera dan lambang Aceh diatur dalam Qanun Aceh. Selayaknya Qanun Aceh, Rancangan Qanun (Raqan) Bendera dan Lambang Aceh disahkan oleh Gubernur Aceh setelah dibahas dan mendapatkan persetujuan bersama DPRA. Kemudian setelah disahkan, Qanun Bendera dan Lambang Aceh dievaluasi oleh Pemerintah Pusat sebagai bentuk pengawasan untuk memastikan bahwa Qanun tersebut tidak bertentangan dengan ketentuan umum, antar Qanun dan peraturan perundang-undangan yang lebih tinggi.

Rancangan Qanun Bendera dan Lambang Aceh disahkan oleh Gubernur dan DPRA pada 22 Maret 2013 sebagai Qanun Nomor 3 Tahun 2013 Tentang Bendera dan Lambang Aceh dengan menetapkan Bulan-Bintang sebagai Bendera Aceh dan Buraq-Singa sebagai Lambang daerah Aceh. Sesuai dengan mekanisme pengawasan terhadap Qanun Aceh, setelah disahkan oleh Gubernur Aceh dan diundangkan dalam lembaran daerah, Qanun Bendera dan Lambang Aceh dievaluasi oleh Pemerintah Pusat melalui Kementrian Dalam Negeri (Kemendagri). Kemudian Kemendagri bersama dengan Kementrian dan Lembaga Pemerintah Non Kementrian terkait melakukan kajian terhadap Qanun Bendera dan Lambang Aceh dan menyimpulkan bahwa beberapa subtansi Qanun Bendera dan Lambang Aceh bertentangan dengan kepentingan umum dan peraturan perundang-undangan yaitu PP No. 77 Tahun 2007 Tentang Lambang Daerah serta aturan dalam pembuatan legal drafting. Akan tetapi hasil kajian dan evaluasi tersebut mendapat penolakan dari Gubernur Aceh dan Dewan Perwakilan Rakyat Aceh (DPRA) yang kemudian penolakan ini menjadi muara perbedaan pendapat antara Pemerintah Pusat dan Pemerintah Aceh terhadap Qanun Bendera dan Lambang Aceh.

Dari penjelasan di atas, dapat disimpulkan bahwa relasi kewenangan antara Pemerintah Pusat dan Pemerintah Aceh dalam implementasi Undang-Undang Pemerintahan Aceh terutama dalam pengesahan turunan UUPA Qanun Bendera dan Lambang Aceh terjadi dan terjalin pada pengawasan dan pengesahan terhadap Qanun. Pemerintah Aceh melalui Gubernur dan DPRA berkewenangan untuk mengatur tentang bendera dan lambang Aceh dalam sebuah Qanun Aceh. Artinya Gubernur Aceh dapat menentukan bagaimana jenis dan bentuk yang akan digunakan sebagai bendera dan lambang Aceh setelah mendengar berbagai masukan dari seluruh elemen masyarakat Aceh dan mendapat persetujuan bersama dengan DPRA.

Di samping itu, Pemerintah Pusat juga berkewenangan untuk melakukan pengawasan terhadap Qanun Bendera dan Lambang Aceh berupa evaluasi, revisi, penangguhan, sampai dengan pembatalan Qanun. Pengawasan represif yang dilakukan Pememerintah Pusat ini bertujuan untuk memastikan bahwa Qanun Bendera dan Lambang Aceh tidak bertentangan dengan kepentingan umum masyarakat Aceh, aturan sesama Qanun dan peraturan perundangundangan yang lebih tinggi. Artinya, walaupun Provinsi Aceh merupakan salah satu daerah yang diberikan status otonomi khusus oleh Pemerintah Pusat, tetapi dalam pengawasan terhadap Qanun Aceh pola relasi antara Pemerintah Pusat dan Pemerintah Aceh memiliki kesamaan dengan pola pengawasan Pemerintah Pusat terhadap Peraturan Daerah (Perda) di daerah-daerah lainnya di Indonesia.

\section{SIMPULAN}

Dari apa yang telah penulis kemukakan tersebut, dapat disimpulkan bahwa berdasarkan UUPA Pemerintah Aceh memiliki kewenangan untuk menetapkan dan mengesahkan pengaturan tentang bendera dan lambang Aceh dalam Qanun Aceh. Sedangkan Pemerintah Pusat berkewenangan melakukan pengawasan terhadap Qanun Aceh tentang Bendera dan Lambang Aceh yang telah ditetapkan oleh Pemerintah Aceh. Sehingga relasi antara Pemerintah Pusat dan Pemerintah Aceh dalam pengesahan Qanun Bendera dan Lambang Aceh terjadi dan 
terjalin pada aspek kewenangan. Artinya, hubungan yang terjadi antara Pemerintah Pusat dan Pemerintah Aceh ketika masing-masing melaksanakan kewenangannya yang didasari atas perintah konstitusional dari UUPA.

\section{REFERENSI}

Agustino, Leo. 2014. Politik Lokal dan Otonomi Daerah. Bandung : Alfabeta.

Anggraini, Jum. 2011. "Kedudukan Qanun dalam Sistem Pemerintahan Daerah dan Mekanisme Pengawasannya" Jurnal Hukum IUS QUIAIUSTUM No 3 Vol. 18.

Djohan, Djoehermansyah. 2013. "Desentralisasi Asimetris Aceh dan Permasalahannya" Jurnal Ilmu Pemerintahan No. 42.

Isra, Saldi. 2013. "Desentralisasi Asimetris di Indonesia: Kajian Dari Aspek Konstitusi" Jurnal Ilmu Pemerintahan No. 42.

Jaweng, Robert Endi. 2011. "Kritik Terhadap Desentralisasi Asimetris di Indonesia" Jurnal Analisis CSIS Vol. 40 No. 2.

Kurniadi, Bayu Dardias. "Desentralisasi Asimetris Di Indonesia". (Makalah disampaikan dalam Seminar di Lembaga Administrasi Negara (LAN) Jatinangor, tanggal 26 November 2012).

Labolo, Muhadam. 2014. Desentralisasi Asimetrik Di Indonesia: Peluang, Tantangan \& Recovery. Jakarta: Wadi Press.

Tasrin, Krismiyati, dkk. 2012. Kajian Pengembangan Desentralisasi Asimetris. Bandung: Pusat Kajian dan Pendidikan dan Pelatihan Aparatur I Lembaga Administrasi Negara.

Surat Menteri Dalam Negeri No. 188. 34/1664/SJ tertanggal 1 April 20113 perihal Klarifikasi Atas sebagai Qanun Nomor 3 Tahun 2013 Tentang Bendera dan Lambang Aceh.

Surat Gubernur Aceh No. 180/20378 tertanggal 5 April 2013 perihal Tanggapan Terhadap Hasil Klarifikasi Qanun Nomor 3 Tahun 2013 tentang Bendera dan Lambang Aceh.

Surat Ketua DPRA No.188/34/899 tertanggal 11 April 2013 perihal Penyampaian Jawaban atas Klarifikasi Qanun No.3 Tahun 2013 tentang Bendera dan Lambang. 